\title{
Catalogue of type specimens of invertebrates in the collection of the Instituto Nacional de Pesquisas da Amazônia, Manaus, Brazil. II. Hexapoda: Collembola, Diplura, Archaeognatha, Ephemeroptera and Blattaria
}

\author{
José Moacir Ferreira Ribeiro' ${ }^{1}$, Célio Magalhães ${ }^{2,3}$, José Albertino Rafael $^{2,3}$ \& Augusto Loureiro Henriques $^{2}$
}

\author{
${ }^{1}$ Instituto Nacional de Pesquisas da Amazônia, Programa PCI (MCT-INPA/CNPq), Caixa Postal 478, 69.011-970 Manaus, Brazil. \\ moacir@inpa.gov.br \\ ${ }^{2}$ Instituto Nacional de Pesquisas do Amazônia (celiomag, jarafael, loureiro@inpa.gov.br) \\ ${ }^{3}$ Research fellow of the CNPq.
}

\begin{abstract}
Catalogue of type specimens of invertebrates in the collection of the Instituto Nacional de Pesquisas da Amazônia, Manaus, Brazil. II. Hexapoda: Collembola, Diplura, Archaeognatha, Ephemeroptera and Blattaria. A catalogue of type specimens of Collembola, Diplura, Archaeognatha, Ephemeroptera, and Blattaria deposited in the Invertebrate Collection of the Instituto Nacional de Pesquisas da Amazônia (INPA), Manaus, Brazil, is presented and updated to June, 2007. It contains a total of 22 holotypes and 18 lots of paratypes of 22 species of Collembola; one holotype and one paratype of one species of Diplura; four holotypes and four paratypes of four species of Archaeognatha; 10 holotypes and thirteen lots of paratypes of 11 species of Ephemeroptera; and one holotype and two lots of paratypes of one species of Blattaria. Specific names are listed alphabetically within family, followed by bibliographical citation, original genus name, status of type, collection number and locality data.
\end{abstract}

KEYWORDS. Amazon Region; Arthropoda; INPA; taxonomy.

RESUMO. Catálogo dos espécimes-tipo da Coleção de Invertebrados do Instituto Nacional de Pesquisas da Amazônia, Manaus, Brasil. II. Hexapoda: Collembola, Diplura, Archaeognatha, Ephemeroptera e Blattaria. É apresentado um catálogo dos espécimes-tipo de Collembola, Diplura, Archaeognatha, Ephemeroptera e Blattaria depositados na Coleção de Invertebrados do Instituto Nacional de Pesquisas da Amazônia (INPA), Manaus, Brasil, atualizado até junho de 2007. É relacionado um total de 22 holótipos e 18 lotes de parátipos de 22 espécies de Collembola; um holótipo e um lote de parátipos de uma espécie de Diplura; quatro holótipos e quatro parátipos de quatro espécies de Archaeognatha; dez holótipos e sete lotes de parátipos de 11 espécies de Ephemeroptera e um holótipo e dois lotes de parátipos de uma espécie de Blattaria. São listados alfabeticamente em cada família os nomes das espécies, seguidos da citação bibliográfica, nome original do gênero, categoria do tipo, número de registro na coleção e dados de localidade.

PALAVRAS-CHAVE. Arthropoda; INPA; Região Amazônica; taxonomia.

The Collection of Invertebrates of the Instituto Nacional de Pesquisas da Amazônia (INPA) was initiated by Nelson Leandro Cerqueira from 1954 to 1969 based on the specimens, mainly of Culicidae (Insecta: Diptera), that he and his collaborators collected from the vicinities of Manaus and other places from the Amazon region (Hutchings et al. 2005). This collection was kept and improved by Lindalva Paes de Albuquerque until her retirement from the Institute in 1991. However, the formal establishment of the collection occurred in October, 1976 according to the communications of Ratcliffe \& Penny (1978a) and Ratcliffe (1978) to the national and international scientific community, respectively. Insecta is the larger group in the collections holdings, summing up to over 350,000 pinned specimens, approximately the same amount in cotton layers, and a rough estimate of 4 million unsorted individuals in alcohol by the end of 2006. The first catalogue of type specimens included a list of primary and secondary types of 21 families 39 genera and 104 species of insects (63 holotypes and 245 paratypes) (Ratcliffe \& Penny 1978b). The second was published by Rafael et al. (1983) with 12 orders,
41 families, 104 genera and 251 species of Hexapoda (194 holotypes and 462 paratypes). The collection has grown substantially since the early 1980' and the number of types has increased significatively as well. Currently, the type material of more than 900 species is deposited in the collection, of which almost $80 \%$ belongs to various Hexapoda groups.

Except for a list of the types of Tabanidae (Diptera) (Henriques 1995), no updates of this catalogue have been produced since then. Due to the large number of types which would make it impractical to present in a single volume, a sequentially numbered series of catalogues was planned (Magalhães \& Pimpão 2006). This is the second part of this catalogue in which the putative type specimens of five Hexapoda groups, Collembola, Diplura, Archaeognatha, Ephemeroptera and Blattaria deposited in the INPA's Invertebrate Collection up to December, 2007 are listed.

Procedures and format of the present catalogue follow the ones established in the first part of this series (Magalhães \& Pimpão 2006). Most of the specimens deposited at INPA's entomological collection are pinned, but some are preserved 
as microscope slide preparations or in glass vials with $70 \%$ ethanol. If not stated otherwise, the specimens are pinned.

Each order has its own numbering system. However this system encompasses only the type specimens; the holdings of non-type material have no numbers assigned to the specimens. The numbering system refers to the taxon, not to the specimens, so that in some cases holotypes and paratypes can share the same catalogue number (paratype specimens are differentiated by an Arabic numbers or letters between brackets). Each lot of type specimen is prefaced by an abbreviation of the respective order. Text between brackets refers to additional information not included in the original label. Taxonomic classification follows the Hexapoda's phylogenetic relationships proposed by Wheeler et al. (2001a,b).

Notwithstanding our efforts in finding type specimens that were cited in the literature as having been deposited at INPA, up to now some of them have not been found. The present catalogue lists only the types that were effectively desposited in the INPA's holdings.

\section{RESULTS}

A total of 19 holotypes and 18 lots of paratypes of 22 species of Collembola; one holotype and one paratype of one species of Diplura; four holotypes and four paratypes of four species of Archaeognatha; ten holotypes and seven lots of paratypes of 11 species of Ephemeroptera; and one holotype and two lots of paratypes of one species of Blattaria are reported.

\section{List of type specimens Class ELIPLURA Order COLLEMBOLA BOURLETIELLIDAE}

fuscus Bretfeld, 2002: 113, figs. 18-22. Adisius.

Holotype: female, COLLE 004, mounted in four slides (a, b, c, d). Brazil, Amazonas, Reserva Florestal Adolpho Ducke near Manaus, terra firme, 27.vii.1994, Leg. J. Adis et al. Paratype: male, COLLE 004, slide; data as holotype.

Remarks. The Adisius name was in homonímia and was substituted by Adisianus of the same author in the work of Bretfeld, 2003.

maculatus Bretfeld, 2002: 111, figs. 1-17. Adisius.

Holotype: male, COLLE 003, alcohol; Brasil, Amazonas, Reserva Florestal Adolpho Ducke near Manaus, terra firme, 26.vii.1994, Leg. J. Adis et al. Paratypes: 6 spec., COLLE 003 in six slides; data as holotype.

Remarks. The Adisius name was in homonímia and was substituted by Adisianus of the same author in the work of Bretfeld, 2003.

\section{HYPOGASTRURIDAE}

coeca Oliveira \& Thibaud, 1988: 300, figs. 1-8. Willemgastrura.

Holotype: female, COLLE 025, slide. Brasil, Amazonas, Manaus, ilha da Marchantaria, 16.xi.1986, Leg. E. Oliveira. Paratypes: 3 spec., COLLE 025, all in the same slide; data as holotype.

\section{ISOTOMIDAE}

virgata Deharveng \& Oliveira, 1994: 443, fig. 1-10. Paracerura.

Holotype: male, COLLE 023, slide. Brazil, Amazonas, Manaus, Route ZF-02, Km 14 forêt primaire, 06.xi.1992, Leg. E. Oliveira \& Sena. Paratypes: 5 spec., COLLE 023, in five slides; data as holotype.

\section{KATIANNIDAE}

aureussetosus Bretfeld, 2002: 118, figs. 43-47. Sminthurinus.

Holotype: female, COLLE 008, slide (a-d). Brazil, Amazonas, [Reserva Florestal Adolpho Ducke near Manaus, terra firme], 21.ii.1992, Leg. Adis et al.

cupiubae Bretfeld, 2002: 116, figs. 32-39. Arborianna.

Holotype: male, COLLE 005, alcohol. Brazil, Amazonas, Reserva Florestal Adolpho Ducke near Manaus, terra firme, 27.vii.1994, Leg. J. Adis et al. Paratypes: 13 spec., COLLE 005 in two vials with alcohol, two and eleven specimens; data as holotype.

\section{ONYCHIURIDAE}

amazonica Oliveira \& Thibaud, 1992: 3, figs. 1-7. Mesaphorura.

Holotype: male, COLLE 024, slide. Brasil, Amazonas, ZF2 in 75 km N from Manaus, 14.ix.1998.

fernandae Oliveira \& Thibaud, 1992: 5, figs. 8-11. Onychiurus. Holotype: female, COLLE 026, slide. Brazil, Pará, Belém, Reserva do Mocambo, EMBRAPA, i-xii.1969, Leg. E. Oliveira. Paratype: COLLE 026, slide; data as holotype.

\section{PSEUDACHORUTIDAE}

herberti Arlé \& Rufino, 1976: 99, figs. 1-12. Pseudachorutes

Paratype: COLLE 022, alcohol; [Brasil, Amazonas], Manaus, rio Cuieiras, 21.xi.1974, Leg. E. Rufino.

\section{SMINTHURIDAE}

caputalba Bretfeld, 2002: 121, figs. 55-67. Sphyrotheca.

Holotype: female, COLLE 007, mounted in three slides (a, b, c). Brazil, Amazonas, Reserva Florestal Adolpho Ducke near Manaus, terra firme, 26.viii.1992, Leg. J. Adis et al. Paratype: male COLLE 007, mounted in three slides $(a, b, c)$; locality data as holotype.

coeruleocapitata Bretfeld, 2002: 123. Figs 68-75. Sphyrotheca.

Holotype: male, COLLE 006, mounted in three slides (a, b, c). Brazil, Amazonas, Reserva Florestal Adolpho Ducke near Manaus, terra firme, 26.viii.1992, Leg. J. Adis et al.

\section{SMINTHURIDIDAE}

bivirgata Bretfeld, 2002: 119. Sphaeridia.

Holotype: male, COLLE 001, mounted in three slides (a, b, c). Brazil, Amazonas, Manaus, Reserva Florestal Adolpho Ducke near Manaus, terra firme, 26.viii.1992, Leg. J. Adis et al.

cerastes Bretfeld \& Gauer, 1994 : 117, figs. 2 (a-e). Sphaeridia.

Holotype: male, COLLE 010, alcohol. [Brazil, Amazonas, Manaus, igapó of Rio Tarumã Mirim near Manaus, 03.x.1989, Leg. U. Gauer]. Paratypes: 2 spec., COLLE 010, mounted in two slides (a,b); data as holotype.

clara Bretfeld \& Gauer, 1994: 116.Figs. 3 (a-c). Sphaeridia.

Holotype: male, COLLE 011, alcohol. [Brazil, Amazonas, Manaus, igapó of Rio Tarumã Mirim near Manaus, 31.x.1990, Leg. U. Gauer]. Paratypes: 4 spec., COLLE 011, in the same vial, alcohol; locality data as holotype

coronata Bretfeld \& Gauer, 1994: 116, fig 4 (a-d). Sphaeridia.

Holotype: male, COLLE 012, alcohol. [Brazil, Amazonas, igapó of Rio Tarumã Mirim near Manaus, 29.viii.1989, Leg. U. Gauer]. Paratypes: 6 spec., COLLE 012, all preserved in a vial with alcohol; data as holotype. 
duckei Bretfeld, 2002: 120, figs. 50-54. Sphaeridia.

Holotype: female, COLLE 002, slide. Brazil, Amazonas, Manaus, Reserva Florestal Adolpho Ducke near Manaus, terra firme, 27.vii.1994, Leg. J. Adis et al.

fibulifera Bretfeld \& Gauer, 1994: 116, fig 5 (a-e). Sphaeridia.

Holotype: male, COLLE 013, alcohol. [Brazil, Amazonas, Manaus, igapó of Rio Tarumã Mirim near Manaus, 03.x.1989, Leg. U. Gauer]. Paratypes: 3 spec., COLLE 013, all in a vial with alcohol; data as holotype.

franklinae Bretfeld \& Gauer, 1994: 120, fig 6 (a-d). Sphaeridia. Holotype: male, COLLE 014, in a vial with alcohol. [Brazil, Amazonas, Manaus, igapó of Rio Tarumã Mirim near Manaus, 31.x.1990, Leg. U. Gaue]. Paratypes: 4 spec., COLLE 014, three in a vial with alcohol in the same vial of holotype and one mounted in slide; data as holotype.

martii Bretfeld \& Gauer, 1994: 121, fig 8 (a-e). Sphaeridia.

Holotype: male, COLLE 016, slide. Brazil, Amazonas, Manaus, igapó of Rio Tarumã Mirim near Manaus, 24.ix.1971, Leg. U. Irmler.

pilleata Bretfeld \& Gauer, 1994: 122, fig 9 (a-e). Sphaeridia.

Holotype: male, COLLE 019, alcohol. [Brazil, Amazonas, Manaus, igapó of Rio Tarumã Mirim near Manaus, 03.x.1989, Leg. U. Gauer]. Paratypes: 3 spec., COLLE 019, two in a vial with alcohol and one mounted in slide; locality data as holotype.

robusta Bretfeld \& Gauer, 1994: 123, fig 10. Sphaeridia.

Holotype: male, COLLE 017, mounted in three slides (a, b, c). Brazil, Amazonas, Manaus, igapó of Rio Tarumã Mirim, 24.ix.1971, Leg. U. Imler.

squamifera Bretfeld \& Gauer, 1994: 125, fig 10 (a-e) Sphaeridia

Holotype: male, COLLE 018, alcohol. [Brazil, Amazonas, Manaus, igapó of Rio Tarumã Mirim, 03.x.1989, Leg. U. Gauer]. Paratypes: 4 spec., COLLE 018, two in a vial with alcohol together the holotype vial and two in slides; locality data as holotype.

\section{STURMIIDAE}

truncivivus Bretfeld \& Gauer, 1999: 280, fig 1-3. Sturmius.

Holotype: female, COLLE 009, alcohol. [Brazil, Amazonas, Manaus, on a living tree trunk in blackwater inundation forest (igapó) near Manaus, 12.ii.1991, Leg. U. Gauer]. Paratypes: 14 spec., COLLE 009 in three vials with alcohol, two with five specimens and the other with four; locality data as holotype.

\section{Class DIPLURA \\ Order DIPLURA \\ PARAJAPYGIDAE}

adisi Pagés, 2000: 214. Parajapyx.

Holotype: male, DIPLU 001, in one slide; Brazil, Am-env [sic], Manaus, Rio Tarumã Mirim blackwater inundation forest, 28.x.1981, Leg. J. Adis. Paratypes: 10 spec., DIPLU 001, all mounted in slides, being one specimen designated as allotype; locality data as holotype.

\section{Class INSECTA Order ARCHAEOGNATHA MEINERTELLIDAE}

adisi Wygodzinsky, 1978: 303, fig 2. Neomachilellus.

Holotype: male, ARCHA 001, alcohol. [Brazil, Amazonas, Tarumã Mirim, near Manaus, no date, Leg. J. Adis]. Paratypes: 7 spec., ARCHA 002 in five vials with alcohol, three with one specimen and two with two specimens, being one the allotype; data as holotype.

adisi Sturm, 1983: 791. figs. 13-15. Meinertellus.

Holotype: male, ARCHA 005, mounted in two slides (a,b). [Brazil, 20 Km NW] Manaus, [Rio Tarumã Mirim], 18.viii.1979, Leg. J. Adis. Paratypes: 2 spec.,females, ARCHA 006, mounted in two slides $(\mathrm{a}, \mathrm{b})$; locality data as holotype. amazonicus Sturm, 1983: 803, figs. 42-54. Neomachilellus.

Holotype: male, ARCHA 007, mounted in two slides (a,b). [Brazil, Amazonas], Manaus, [ZF2, BR-174], viii.1979, Leg. J. Adis et al. Paratype: female, ARCHA 008, mounted in two slides $(\mathrm{a}, \mathrm{b})$; data as holotype.

scandens Wygodzinsky, 1978: 304, figs. 4-5. Neomachilellus.

Holotype: male, ARCHA 003, alcohol. [Brazil, Amazonas, Tarumã Mirim, near Manaus, no date, Leg. J. Adis]. Paratype: female, ARCHA 004, in a vial with alcohol; date of collection unknown.

\section{Order EPHEMEROPTERA CAENIDAE}

irmleri Puthz, 1975: 411. figs. 1-7. Brasilocaenis.

Holotype: male imago, EPHEM 001, in a vial with alcohol. Brazil, Amazonas, Manaus, lago Murutú, 05.x.1971, Leg. U. Irmler.

\section{LEPTOPHLEBIIDAE}

amazonicus Savage \& Peters, 1983: 556, figs. 19-21, 63, 102, 116, 128-129, 158, 168. Miroculis (Atroari).

Holotype: male imago, EPHEM 014, in a vial with alcohol, except right and left hindwings. Brazil, Amazonas, Rio Marauia, armadilha de luz, 10.i.1963, Leg. E. J. Fittkau.

arsia Savage \& Peters, 1983: 580, figs. 35-39, 78-80, 94, 168. Hermanellopsis.

Holotype: male subimago, EPHEM 016, in a vial with alcohol. Brazil, Amazonas, Rio Cuieiras, 24.iv.1061, Leg. E. J. Fittkau.

duckensis Savage \& Peters, 1983: 554, figs. 49-50, 64, 114-115, 127, 168. Miroculis (Atroari).

Holotype: male imago, EPHEM 012, in a vial with alcohol and parts mounted in three slides, one with one leg, one with right fore and hindwings and one with genitalia. Brazil, Amazonas, Reserva Florestal Adolpho Ducke, 26.vi.1961, Leg. E. J. Fittkau. Paratypes: 6 spec., EPHEM 012, two mounted in two slides and four in four vials with alcohol; locality data as holotype.

fittkaui Savage \& Peters, 1983: 529, figs. 10-12, 45-46, 58-60, 81-82, 91, 96, 97-98, 124-125, 168. Miroculis (Miroculis).

Holotype: male imago, EPHEM 011, in a vial with alcohol. Brazil, Pará, Akahe Creek, near Tiriyos, 15.iii.1962, Leg. E. J. Fittkau. Paratypes: 22 spec., EPHEM 011, in seven vials with alcohol, one with two specimens, one with one specimen, one with four specimens, one with one specimen, one with six specimens, one with one specimen, one with four specimens (one is allotype), and three mounted in three slides.

froehlichi Ferreira \& Dominguez, 1992: 179, figs. 1-7. Hermanella (Guayakia).

Paratypes: 27 spec., EPHEM 017, in three vials with alcohol: one with 15 specimens, one with ten specimens and one with two specimens. Brazil, São Paulo, Córrego do Pedregulho, viiviii.1989, Leg. M. J. N. Ferreira \& C. Froehlich.

maculatus Savage \& Peters, 1978: 294, figs. 1-14, 15-24. Fittkaulus.

Holotype: male imago, EPHEM 002, specimen in two vials with alcohol, one with nymphal exuvia, one with one specimen and parts mounted in three slides: one with leg, one with right fore wing and one with genitalia. Brazil, Pará, Akahe Creek, near Tiriyos, 15.iii.1962, Leg. E. J. Fittkau. Paratypes: $10 \mathrm{spec}$, in three vials with alcohol and one slide: EPHEM 003, imago (allotype), EPHEM 004 with six specimens, with part of paratype mounted in a slide and EPHEM 005 with three specimens; data as holotype.

marauiae Savage \& Peters, 1983: 517, figs. 13-15, 57, 99-102, 121-123, 142-147, 157, 168. Miroculis (Miroculis).

Holotype: male, EPHEM 006, specimen in one vial with alcohol and parts mounted in two slide: one with right fore and hindwings and one with genitalia. Brazil, Amazonas, Rio Marauia, 28.i.1963, 
Leg. E. J. Fittkau. Paratypes: 14 spec. in four vials with alcohol and two slides: EPHEM 007 being one designated allotype with wings mounted in a slide, EPHEM 008 with three specimens in a vial with alcohol and wing mounted in a slide; EPHEM 009 with two specimens in a vial with alcohol and EPHEM 010 with eight specimens in a vial with alcohol; data as holotype.

oepa Lopes, da Silva \& Py-Daniel 2003 : 196, figs. 1-6, 7-12. Ulmeritoides.

Holotype: male larvae, EPHEM 018, alcohol. Brazil, Roraima, Rio Uraricoera, Igarapé Xiquibá, 14.x.1987, Leg. V. Py-Daniel et al. Paratypes: 12 spec., EPHEM 018 in six vials with alcohol, one with eight nymphs,one with four nymphas, three with legs and one with body. Brazil, Roraima, Rio Uraricoera, Igarapé Vermelho, 12.vii.1987, Leg. V. Py-Daniel \& L. Aquino.

pallida Savage \& Peters,1983: 574, figs. 40-41, 75-76, 168. Microphlebia.

Holotype: male subimago, EPHEM 015, in alcohol with leg and right fore and hindwings mounted in two slides. Brazil, Amazonas, Rio Branquinho, near junction with Rio Cuieiras, $\mathrm{N}$ of Manaus, 19.viii.1961, Leg. E. J. Fittkau. Paratypes: 2 spec., EPHEM 015, in two vial with alcohol, except one paratype with a right fore hiding in a slide; locality data as holotype.

wandae Savage \& Peters, 1983: 546, figs. 61-62, 103-104, 168. Miroculis (Yaruma).

Holotype: male subimago, EPHEM 013, in a vial with alcohol, except genitalia in a slide and right fore and hindwings mounted in one slide. Brazil, Amazonas, Rio Marauia, 03.ii.1963, Leg. E. J. Fittkau.

\section{Order BLATTARIA BLABERIDAE}

fenestrata Zompro \& Fritzsher, 1999: 213, figs 1-4. Lucihormetica.

Holotype: male, BLATT 001, in a vial with alcohol. Brazil, Amazonas, Tarumã-Mirim, 29-30.v.1980, Leg. J. Adis. Paratypes: 10 spec., BLATT 001, in eight vials with alcohol; locality data as holotype.

Acknowledgments. J.M.F.R thanks the Instituto Nacional de Pesquisas da Amazônia for scholarships received in the PCI Program (MCT-INPA/CNPq). C.M. and J.A.R. thanks CNPq for ongoing research grants. We are grateful to B. Robertson for correcting the English text, J. Adis and G. Bretfeld for their valuable comments on our manuscript

\section{REFERENCES}

Arlé, R. \& E. Rufino. 1976. Contribuição ao conhecimento dos Pseudachorutidae da Amazônia (Collembola). Acta Amazonica 6: 99-107.

Bretfeld, G. 2002. Known and new genera and species of Symphypleona (Insecta, Collembola) obtained by canopy fogging in Central Amazonia, Brazil. Amazoniana 17: 109-137.

Bretfeld, G. 2003. Adisianus nom. nov. for a genus of Symphypleona (Insecta, Collembola) from Central Amazonia, Brazil. Amazoniana 14: $551-552$.

Bretfeld, G. \& U. Gauer. 1994. Diagnostic description of the males of new Sphaeridia species (Insecta, Collembola) from South America. Andrias 13: 113-136.

Bretfeld, G. \& U. Gauer. 1999. A second species of the genus Sturmius Bretfeld, 1994; Sturmius trincivivus n. sp. from Brazil (Insecta, Collembola, Symphypleona). Amazoniana 15: 279-284.

Deharveng, L. \& E. P. de Oliveira. 1994. Paracerura virgata n. g., n. sp. (Collembola, Isotomidae) nouveau Collembole d'Amazonie centrale. Revue suisse de Zoologie 101: 441-446.

Ferreira, M. J. N. \& E. Dominguez. 1992. A new species of Hermanella (Ephemeroptera: Leptophlebiidae: Atalophlebiinae) from southeastern Brazil. Aquatic Insects 14: 179-182.

Henriques, A. L. 1995. A Coleção de Tabanidae (Insecta: Diptera) do Instituto Nacional de Pesquisas da Amazônia (INPA), Manaus, Amazonas, Brasil. Boletim do Museu Paraense Emílio Goeldi, sér. Zool. 11: 57-99.

Hutchings, R. S. G.; M. A. M. Sallum; R. L. M. Ferreira \& R. W. Hutchings. 2005. O acervo de mosquitos (Diptera, Culicidae) de Nelson L. Cerqueira na Coleção de Invertebrados do Instituto Nacional de Pesquisas da Amazônia, Manaus, Brasil. Revista Brasileira de Entomologia 49: 15-28.

Lopes, M. J. N.; E. R. Da-Silva \& V. Py-Daniel. 2003. A New species of Ulmeritoides from Brazil (Ephemeroptera: Leptophlebiidae). Revista de Biologia Tropical 51: 195-200.

Magalhães, C. \& D. M. Pimpão 2006. Catalogue of type specimens of invertebrates in the collection of the Instituto Nacional de Pesquisas da Amazônia, Manaus, Brazil. I. Acanthocephala, Nematoda, and Rotifera. Revista Brasileira de Zoologia 23: 630-636.

Oliveira, E. P. de \& J-M. Thibaud. 1988. Un nouveau genre d'insecte Collembole Hypogastruridae d'Amazonie. Amazoniana 10: 299 302.

Oliveira, E. P. de \& J-M. Thibaud. 1992. Notes sur les Collemboles de l'Amazonie, Brésil. 1. Hypogastruridae et Onychiuridae, avec la description de deux espéces nouvelles (Collembola). Opuscula Zoologica Fluminensia 95: 1-8.

Pagés, J. 2000. Parajapyx $(P)$. adisi n. sp., le premier Diplura Parajapygidae des forêts inondables de l'Amazonie centrale. Amazoniana 16: 213-222.

Puthz, V. 1975. Eine neue Caeniden Gattung aus dem Amazonasgebiet (Insecta: Ephemeroptera: Caenidae). Amazoniana 5: 411-415.

Rafael, J. A.; N. D. Penny \& A. Y. Harada. 1983. Relação dos tipos de invertebrados depositados na Coleção de Entomologia Sistemática do INPA - Manaus, até dezembro de 1982. Acta Amazonica 13: 911-926.

Ratcliffe, B. C. 1978. The systematic Entomology Collection of Brazil's National Institute for Amazonian Research (INPA). Bulletin of the Entomological Society of America 24: 62.

Ratcliffe, B. C. \& N. D. Penny. 1978(a). As coleções de entomologia do Instituto Nacional de Pesquisas da Amazônia (INPA - Manaus) Ciência e Cultura 30: 627-628.

Ratcliffe, B. C. \& N. D. Penny. 1978(b). Catálogo dos tipos de invertebrados depositados nas coleções entomológicas do INPAManaus. Acta Amazonica 8: 689-697.

Savage, H. M. \& W. L. Peters. 1978. Fittkaulus maculatus a new genus and species from northern Brazil (Leptophlebiidae: Ephemeroptera). Acta Amazonica 8: 293-298.

Savage, H. M. \& W. L. Peters. 1983. Systematics of Microculis and related genera from northern south America (Ephemeroptera: Leptophlebiidae).Transactions of the American Entomological Society 108: 491-600.

Sturm, H. 1983. Contribución al conocimiento de los Machiloidea de Colombia (Archaaeognatha: Insecta). Caldasia 13: 787-816.

Wheeler, W. C.; M. Whiting; Q. D. Wheeler \& J. M. Carpenter. 2001a. The phylogeny of the extant hexapod orders. Cladistics 17: 113169.

Wheeler, W. C.; M. Whiting; Q. D. Wheeler \& J. M. Carpenter. 2001b. Erratum. The phylogeny of the extant hexapod orders. Cladistics 17: 403-404.

Wygodzinsky, P. 1978. Two new species of Neomachilellus Wygodzinsky (Meinertellidae, Microcoryphia) from the State of Amazonas, Brazil. Acta Amazonica 8: 303-307.

Zompro, O \& I. Fritzsher. 1999. Lucihormetica fenestrata n. gen., n. sp., the first record of luminescence in an orthopteroid insect (Dictyoptera: Blaberidae: Blaberinae: Brachycolini). Amazoniana 15: 211-219.

Received 27/11/2007; accepted 17/08/2008 